\title{
Antioxidánsok - antioxidánssokk: tények és kérdések, 2015
}

\author{
Hagymási Krisztina dr. - Egresi Anna dr. - Lengyel Gabriella dr. \\ Semmelweis Egyetem, Általános Orvostudományi Kar, II. Belgyógyászati Klinika, Budapest
}

\begin{abstract}
Az elmúlt években nagy jelentőséget tulajdonítottak az antioxidáns-kezelésnek az oxidatív stresszel összefüggő betegségek megelőzésében, illetve kezelésében. A kezdeti sikerek után azonban bizonyos antioxidánsok nem kívánt hatásairól, toxicitásáról, prooxidáns tulajdonságáról számoltak be (CARET, ATBC vizsgálat). A későbbi metaanalízisek eredményei sem támasztották alá az antioxidáns-pótlás alkalmazását az elsődleges és a másodlagos megelőzésben. A szerző́k áttekintik az antioxidánsok prooxidáns tulajdonságait, valamint a jelátviteli folyamatokban, a sejtmúködés befolyásolásában betöltött szerepüket. Az antioxidánsok kombinált alkalmazása előnyösebb, amelynek lehetséges magyarázatát összegzik a szerzők. Orv. Hetil., 2015, 156(47), 1884-1887.
\end{abstract}

Kulcsszavak: oxidatív stressz, antioxidánsstressz, antioxidáns vitaminok, prooxidáns, jelátviteli folyamatok

\section{Antioxidants - antioxidative stress: Facts and questions, 2015}

\begin{abstract}
In the past years great importance has been attributed to antioxidant therapy in the prevention and treatment of disorders developed in connection with oxidative stress. After initial success, undesirable effects, toxicities, and prooxidant effects of antioxidants were reported [CARET, ATBC study]. In addition, metaanalyses failed to confirm the role of antioxidant supplementation in the primary and secondary prevention. The authors review the prooxidant effects of antioxidants, and their role in cell signalling and cell process modulation. Finally, the authors summarize possible explanations why combined use of antiooxidants is more favourable.
\end{abstract}

Keywords: oxidative stress, antioxidative stress, antioxidant vitamins, prooxidant, cell signalling

Hagymasi, K., Egresi, A., Lengyel, G. [Antioxidants - antioxidative stress? Facts and questions, 2015]. Orv. Hetil., 2015, 156(47), 1884-1887.

(Beérkezett: 2015. augusztus 18.; elfogadva: 2015. szeptember 13.)

\section{Rövidítések}

AP- 1 = aktivátor protein- 1 ; HIF- $1 \alpha=$ hipoxia indukálta faktor$1 \alpha$;GF-IR = inzulinszerü növekedési faktor receptor; NF- $\kappa \mathrm{B}$ = nuclear factor kappa-B; $\mathrm{PK}=$ proteinkináz; $\mathrm{RARE}=$ retinsav; $\mathrm{TET}=$ ten-eleven translocation methylcytosine; TGF- $\alpha=$ transzformáló növekedési faktor- $\alpha$

Az utóbbi években kiemelkedő szerepet tulajdonítottak az antioxidáns-kezelésnek a kóros szabad gyökös reakciókkal összefüggő betegségek megelőzésében, illetve kezelésében $[1,2]$. Legelőször az ATBC, illetve CARET vizsgálatban számoltak be az antioxidánsok nem kívánt hatásairól (retinol, $\beta$-karotin-kezelések a tüdőtumor előfordulását növelték) [3]. Későbbi áttekintések sem igazolták a napi ajánlott táplálkozási bevitelt meghaladó mennyiségü („supra-nutritional”) antioxidáns-pótlás hatásosságát az elsődleges és másodlagos megelőzésben $[4,5]$.

\section{C-vitamin}

A C-vitamin vízoldékony antioxidáns, elektrondonor tulajdonsága révén redukálószer [6]. Számos enzim kofaktora (prolil-, lizilhidroxiláz), szerepet játszik a koleszterinmetabolizmusban, a citokróm P450 múködésében, a neurotranszmitterek, valamint a karnitin szintézisében [6]. Az aszkorbát epigenomikai folyamatokat befolyásol a DNS- és a hisztondemetiláció szabályozásával, mivel esszenciális kofaktora a TET (ten-eleven translocation methylcytosine) dioxigenázoknak, valamint a Jmjc domént tartalmazó hisztondemetilázoknak [7].

Kis koncentrációban a C-vitamin redukálja az átmeneti fémionokat, elősegíti a fémkatalízist a Fenton-reakcióban, s ezzel a lipidperoxidáció folyamatát katalizálja [2]. Nagy mennyiségú C-vitamin $(500 \mathrm{mg} / \mathrm{ttkg} / \mathrm{nap} / 4$ napon át) a citokróm $\mathrm{P} 4502 \mathrm{El}$ a monooxigenázokat indukálja, amely szuperoxidanion-felszabadulással jár [8]. A citokróm P450 enzimek aktivitásának befolyásolásával 
gyógyszerhatóanyagok (acetaminofen, teofillin) metabolizmusát befolyásolhatja, illetve prokarcinogének (N-nitrózaminok) aktiválását eredményezheti. Az alkoholfogyasztás is fokozott mikroszomális enzimindukciót eredményez, amelynek C-vitamin-bevitel esetén fokozott szabadgyök-felszabadulás a következménye, ezért rendszeres alkoholfogyasztókban a megengedhető mennyiség 100-500 mg/nap lehet [8]. A C-vitamin genotoxicitását a xantinoxidáz múködését fokozó hatása révén keletkező szuperoxid anion okozza [8].

A redoxérzékeny molekuláris folyamatok befolyásolásával - bár a lipofil antioxidánsokhoz képest kevésbé jelentős módon - hat a sejtmúködésre. A NADPHoxidáz-expresszió gátlása, fehérje-tirozinkinázok, -foszfatázok, transzkripciós faktorok (HIF-l $\alpha, \mathrm{AP}-1$ ) aktivitásának befolyásolása lehetséges magyarázatot ad a jelátvivő folyamatokat befolyásoló hatására [9].

\section{A C-vitamin daganatellenes hatása}

Az aszkorbinsav daganatellenes hatása hátterében korábban a kollagénszintézist fokozó, illetve a hialuronidázt gátló hatását vélték. Az aszkorbinsav prooxidáns, illetve a sejtmúködést befolyásoló hatásai is segíthetik a daganatellenes kezelést [6].

Daganatellenes hatásának hátterében az iv. alkalmazott aszkorbátból az extracelluláris térben keletkező aszkorbátgyök, valamint a következményesen képződő $\mathrm{H}_{2} \mathrm{O}_{2}$ citotoxikus hatása, a daganatsejtek ATP-depléciója; a sejtmagból történő fokozott rézmobilizáció s következményes lipidperoxidáció, DNS-károsodás; az aszkorbinsav oxidált formájából a homocisztein-tiolaktonnal reagálva a toxikus 3-merkaptopropion-aldehid képződése; az inzulinszerü növekedési faktor receptor (IGF-IR) és az IGF-II-termelés csökkentésén keresztül az angiogenezis gátlása; a mitokondriális membránpotenciál csökkentésével a citokróm c felszabadulásával az apoptózis; valamint a sejthalál kaszpázfüggetlen formáinak (autoszkízis, autofágia) serkentése; illetve az interferon- $\gamma$-t indukáló IL-18-termelés csökkentése, az immunrendszert befolyásoló hatásai állhatnak $[6,10]$.

A C-vitamin tumorellenes hatását esettanulmányokban, megfigyeléses vagy kontroll nélküli vizsgálatokban írták le. Jacobs és mtsai a témában 1946 és 2014 között megjelent közlemények metaanalízisét végezték el, áttekintésük alapján nem áll rendelkezésre elegendő bizonyíték, hogy a C-vitamin-pótlás segítené a kemoterápia hatékonyságát vagy csökkentené toxicitását daganatos betegekben [11].

\section{Béta-karotin/A-vitamin}

A lipofil antioxidáns fiziológiás körülmények között (15-20 torr oxigénnyomás) antioxidánsként, míg a külső légnyomás körülményei között (760 torr) prooxidánsként múködik, ez utóbbi tulajdonsága egyértelmú magasabb oxigénnyomású szövetekben (például tüdő).
Prooxidáns tulajdonsága koncentrációfüggő, s előtérbe kerül az antioxidáns-védelem gyengesége, idült oxidatív stressz (például dohányzás) esetén is [12].

Ismert, hogy a dohányfüstben megtalálható vagy az asbestosis okozta gyulladás következtében felszabaduló szabad gyökök, illetve a vitamin autooxidációja következtében is karotinoid-szabadgyökök keletkeznek. Monooxigenáz izoenzimek indukciójának szabadgyök-túlprodukció a következménye [13]. A béta-karotin-kezelés az antioxidáns védelmet gyengíti ( $\alpha$-tokoferolfelhasználás, redukált glutation szintjének csökkentése), az antioxidáns enzimek (szuperoxid dizmutáz, glutation-transzferáz, kataláz, glutation-peroxidáz) aktivitását koncentrációtól és oxigénnyomástól függően befolyásolja [14]. A glutation-S-transzferáz $\pi$ gátlásával a DNSaddukt-képződést serkenti [5].

Számos sejtfolyamatot befolyásol (sejtproliferáció, -differenciáció, apoptózis), antioxidáns tulajdonságától függetlenül, a jelátvitelben betöltött szerepe, transzkripciós faktorok aktivitásának befolyásolása révén (RARE: retinsav-response element). Körülbelül 500-ra tehető a szabályozott gének száma (home-box doméneket tartalmazó gének, cinkujjproteineket kódoló gének, citoszolikus zsírsavkötő fehérjék, tirozinkináz/proteinkinázok, transzkripciós faktorok: NF-кB, AP-1, helix-loop-helix DNS-kötő domén, rövidlánc-dehidrogenázok, TGF- $\alpha$ propeptid domének) $[14,15]$.

\section{E-vitamin}

A lipofil E-vitamin (tokoferolok, tokotrienolok) biztonságos táplálkozási antioxidánsunknak tekinthető, de nagy koncentrációban daganatmegelőző tulajdonsága nem egyértelmú. Nagy koncentrációban szabad gyökök képződéséhez vezethet, prooxidánsként viselkedhet. Az E-vitamin oxidált terméke a tokoferoxilgyök. Ha a szervezetben nincs megfelelő, a gyököt regenerálni képes más antioxidáns, az E-vitamin az LDL-oxidációt elősegíti [16]. Nem feltétlenül antioxidáns tulajdonsága révén (direkt kötődés, alegység-összeszerelés gátlása, membrántranszlokáció gátlása) számos sejtfolyamatot (sejtproliferáció, thrombocytaaggregáció, monocytaadhaesio, eikozanoidszintézis) befolyásol enzimekkel (foszfolipáz A2, ciklooxigenáz, lipoxigenáz, proteinkinázok), szerkezeti fehérjékkel, lipidekkel és transzkripciós faktorokkal $(\mathrm{NF}-\kappa \mathrm{B}, \mathrm{AP}-1, \mathrm{HIF}-1 \alpha)$ való kölcsönhatásával $[9,17$, 18]. Ugyanúgy, mint a béta-karotin, a glutation-Stranszferáz $\pi$ gátlása lehet a felelős a fokozott DNS-addukt-képződésért, s a nem kívánt halálozási adatokért dohányosokban [5].

\section{Polifenolok/flavonoidok}

A polifenolos vegyületek, flavonoidok antioxidáns tulajdonsága direkt szabadgyök-scavenger tulajdonságukhoz, H-donor-aktivitásukhoz, antioxidáns enzimek aktiválásához, kelátképzésükhöz, az alfa-tokoferoxil-gyök 
semlegesítéséhez, az oxidázok gátlásához, a kis molekulasúlyú antioxidánsok (béta-karotin) antioxidáns aktivitásának növeléséhez köthető [19].

Prooxidáns tulajdonságuk koncentrációfüggő, függ az OH-csoportok számától (különösen a B-gyưrúben), a pirogallolszerkezettől az A-gyưrúben, a 2,3-kettős kötéstől és a flavonok 4-oxo-szerkezetétől [19]. Szabadgyök-befogás, autooxidációjuk, a mieloperoxidáz enzim múködése következtében az igen reaktív flavonoid fenoxilgyök keletkezik. A flavonoid kinonok kevésbé reaktívak, mert a nukleofil redukált glutation, a cisztein vagy a nukleinsavak stabilizálhatják. A fenoxilgyökök az NADH-t oxidálják, valamint átmeneti fémionok jelenlétében szuperoxid anion képződik. Az autooxidáció pH-függő, az átmeneti fémionok serkentik [19]. Bizonyos polifenolok (katechol, luteolin, eriodiktiol, kvercetin) kis molekulájú antioxidánsokat (aszkorbát, NADH, GSH) oxidálnak, illetve a kis molekulasúlyú antioxidánsok felszívódását gátolhatják (például a naringenin gátolja a lutein felszívódását) [19]. Az átmeneti fémionok $\left(\mathrm{Fe}^{3+}, \mathrm{Cu}^{2+}\right)$ redukálásával a lipidperoxidációt segítik. A kromatinkötött réz mobilizációjával prooxidáns hatása sejthalált okoz. A Fe(II)-flavonoid komplex direkt DNSkárosító [20]. A polifenolok gátolják a nem hem vas, a folsav felszívódását, a pajzsmirigyhormonok szintézisét. Lebontásuk a xenobiotikumok metabolizmusát is végző enzimrendszerek segítségével történik, valamint a citokróm P450 enzimrendszerek (CYP3A4, 3A5, CYP1A2, CYP2C9), a fázis II enzimek (UDP-glükuronil-transzferáz, szulfotranszferázok, glutation-S-transzferáz), valamint gyógyszertranszporterek (P-glikoprotein, multi- drogrezisztencia-asszociált fehérje, emlőrák-rezisztencia fehérje) befolyásolásával hatással lehetnek más gyógyszerhatóanyagok farmakokinetikájára [21]. A zöldteapolifenolok az NF-кB aktivációját gátolhatják, s ezzel jelátviteli folyamatokat befolyásolhatnak [18]. A kvercetin az AP-1-hez közvetlenül kötődik, ezáltal befolyásolja aktivitását és a jelátviteli folyamatokat.

A sztilbénszármazék reszveratrol direkt kötődés (c-Src, PK), a proteoszomális degradáció gátlása $(\mathrm{NF}-\kappa \mathrm{B})$ vagy az alegység-összeszerelés változása ( $\mathrm{AP}-1)$ révén, nem antioxidáns tulajdonságai által befolyásolhatja a sejtfolyamatokat [19].

\section{Antioxidánsok kombinált alkalmazása}

Potter 200 epidemiológiai vizsgálat eredményét elemezve arra a következtetésre jutott, hogy az antioxidánsok kombinált alkalmazása hatékonyabb, mint önállóan történő bevitelük [22]. Számos, a legmagasabb evidenciát szolgáltató, placebokontrollált, randomizált vizsgálat indult a kombinált antioxidáns kezelés és/vagy szupplementáció hatásának lemérésére.

\section{Antioxidánsok interakciója}

Jellemző, hogy az egyes gyökbefogók jelentősen szelektívek azokra a gyökökre, amelyekkel reagálnak (E-vitamin: lipidperoxid, szuperoxid anion, szinglet oxigén; C-vitamin: lipidperoxid, szuperoxid anion, szinglet oxigén, hidroxil-anion; A-vitamin: oxigén; flavonoidok: li-

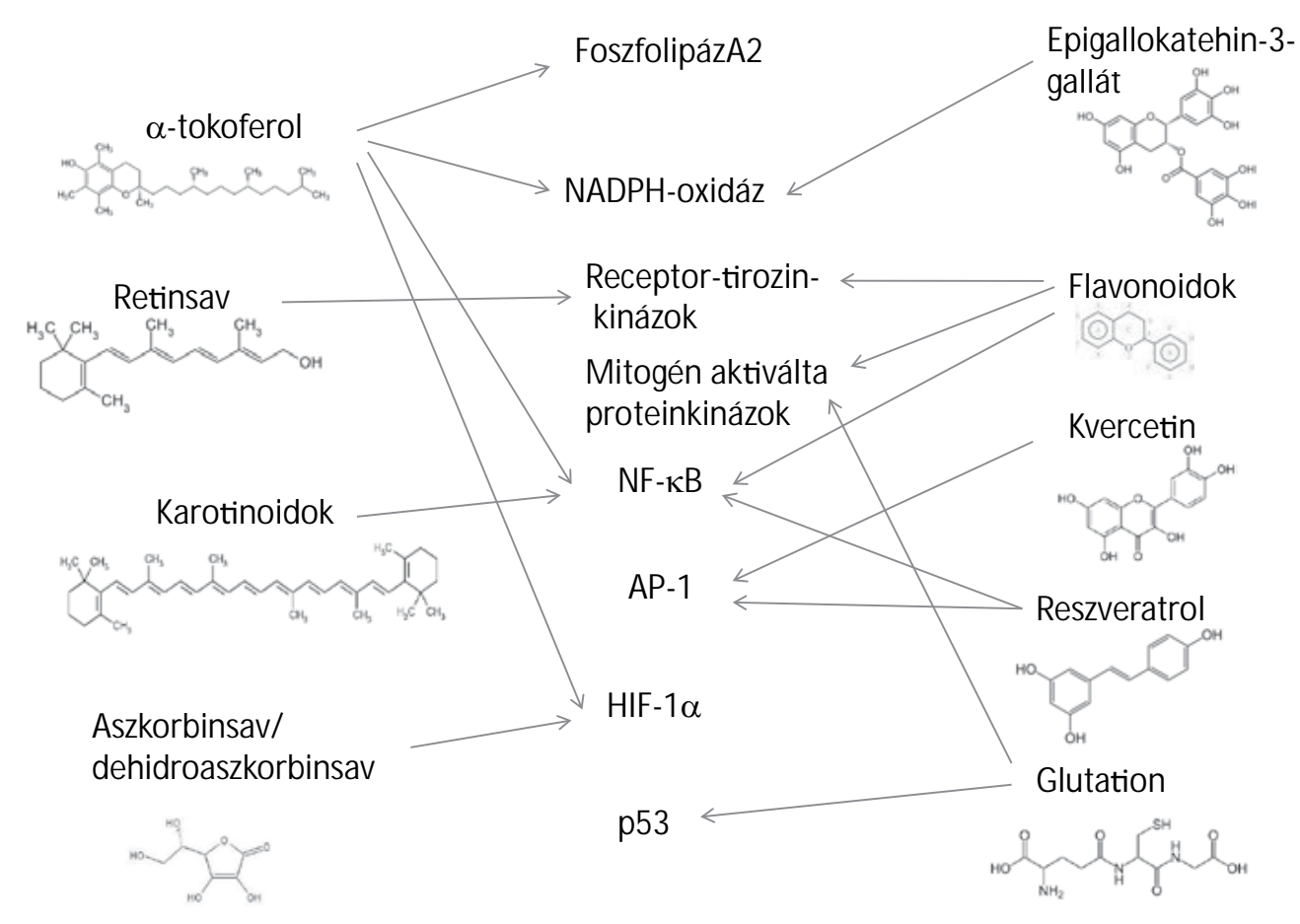

1. ábra

| Antioxidánsaink jelátvitelt befolyásoló nem antioxidáns hatásai 
pidperoxid, szuperoxid anion, hidroxil-anion). Az antioxidánsok a lipidperoxidáció különbözô fázisaiban hathatnak (iniciáció gátlása: E-vitamin; propagáció gátlása: E-vitamin, C-vitamin). Az egyes antioxidánsok másmás szöveteket, szubcelluláris kompartmenteket védenek (lipofil: E-vitamin, karotinoidok, tokoferolok, flavonoidok; hidrofil: C-vitamin). Az antioxidánsok szövetspecificitása is ismert. A C-vitamin a nagy szabadgyök-generáló képességgel bíró szövetekben (szem, agy, máj, tüdő, szív, ondó és leukocyták) koncentrálódik, míg az A-vitamin fó raktározója a máj. Az antioxidánsok közvetlen kölcsönhatásban is állhatnak egymással, egymást regenerálhatják [8].

$\mathrm{Az}$ antioxidánsok rossz vízoldékonysága, kémiai instabilitása, elégtelen felszívódása, gyors metabolizmusa, kiválasztódása áll a kis hozzáférhetőségük hátterében. Az antioxidáns-pótlást vizsgáló tanulmányokban a vizsgált dózisok nagyobbak voltak, mint a kiegyensúlyozott táplálkozással bevihető vagy az ajánlott napi mennyiségek, vagy akár a tolerálható felső határérték. Az elérni kívánt farmakológiai hatások miatt alkalmazott nagy dózisok tehetők felelőssé a nem kívánt hatások, mellékhatások kialakulásáért. A figyelem a gyógyszerkibocsátó rendszerek (liposzomák, szolid lipid-nanopartikulumok, polimer nanopartikulumok, nanoszferák, nanokapszulák, dendrimerek, ciklodextrinek) felé irányul, amelyek segítségével az antioxidánsok kisebb koncentrációban, célzottan, nagyobb hatékonysággal, kevesebb mellékhatással alkalmazhatóak (kurkumin, reszveratrol, C-citamin, retinsav, glutation) [9].

\section{Következtetések}

Napjainkban az antioxidáns-pótlás elterjedt, ugyanakkor az antioxidánsok pontos szerepe ellentmondásos, nincs egyetértés az alkalmazott mennyiségről. Metaanalízisek sem igazolták a nagy dózisú antioxidáns-pótlás jogosultságát. Az antioxidánsok maguk is szabad gyökök, de reakciósebességük nagyságrendekkel kisebb, mint az úgynevezett radikális gyököké, ezért koncentrációfüggően prooxidáns karakterük is érvényre jut. Az általános antioxidáns tulajdonság érvényét vesztette, sejtfolyamatokban jelátvivők, jelátvivő folyamatokat, génexpressziót módosítók (1. ábra). Kombinált, természetes formában történő alkalmazásuk mindenképpen előnyösebbnek tünik [10].

Anyagi támogatás: A közlemény megírása anyagi támogatásban nem részesült.

Szerzői munkamegosztás: H. K., E. A.: Adatgyưjtés, a kézirat megszövegezése. H. K., L. G.: A kézirat áttekintése. A cikk végleges változatát a szerzők elolvasták és jóváhagyták.

Érdekeltségek: A szerzőknek nincsenek érdekeltségeik.

\section{Irodalom}

[1] Elahi, M. M., Kong, Y. X., Matata, B. M.: Oxidative stress as a mediator of cardiovascular disease. Oxid. Med. Cell. Longev., 2009, 2(5), 259-269.

[2] Poljsak, B., Milisav, I.: The neglected significance of "antioxidative stress". Oxid. Med. Cell. Longev., 2012, 2012, 480895.

[3] Albanes, D., Heinonen, O. P., Taylor, P. R., et al.: Alpha-tocopherol and beta-carotene supplements and lung cancer incidence in the alpha-tocopherol, beta-carotene cancer prevention study: effects of base-line characteristics and study compliance. J. Natl. Cancer Inst., 1996, 88(21), 1560-1570.

[4] Bjelakovic, G., Nikolova, D., Gluud, L. L., et al.: Antioxidant supplements for prevention of mortality in healthy participants and patients with various diseases. Sao Paulo Med. J., 2015, 133(2), 164-165.

[5] Vrolijk, M. F., Opperhuizen, A., Jansen, E. H., et al.: The shifting perception on antioxidants: the case of vitamin $E$ and $\beta$-carotene. Redox Biol., 2015, 4, 272-278.

[6] Lee, W. J.: The prospects of vitamin $\mathrm{C}$ in cancer therapy. Immune Netw., 2009, 9(5), 147-152.

[7] Young, J. I., Züchner, S., Wang, G.: Regulation of the epigenome by vitamin C. Annu. Rev. Nutr., 2015, 35, 545-564.

[8] Hagymási, K., Blázovics, A.: Antioxidants in liver protection. [Antioxidánsok a májvédelemben.] Orv. Hetil., 2004, 145(27), 1421-1425. [Hungarian]

[9] Leonarduzzi, G., Sottero, B., Poli, G.: Targeting tissue oxidative damage by means of cell signaling modulators: The antioxidant concept revisited. Pharmacol. Ther., 2010, 128(2), 336-374.

[10] Hagymási, K.: Natural antioxidants: facts and questions. Vitamin C. In: Blázovics, A., Mézes, M. (eds.): Natural agents in modern medicine. [Természetes antioxidánsok: tények és kérdések - Cvitamin. In: Blázovics, A., Mézes, M. (szerk.): Természetes hatóanyagok a modern orvoslásban.] Szent István Egyetemi Kiadó, Gödöllő, 2014. [Hungarian]

[11] Jacobs, C., Hutton, B., Ng, T., et al.: Is there a role for oral or intravenous ascorbate (vitamin $\mathrm{C}$ ) in treating patients with cancer? A systematic review. Oncologist, 2015, 20(2), 210-223.

[12] Palozza, P., Luberto, C., Calviello, G., et al.: Antioxidant and prooxidant role of beta-carotene in murine normal and tumor thymocytes: effects of oxygen partial pressure. Free Radic. Biol. Med., 1997, 22(6), 1065-1073.

[13] Paolini, M., Antelli, A., Pozetti, L., et al.: Induction of cytochrome P450 enzymes and over-generation of oxygen radicals in beta-carotene supplemented rats. Carcinogenesis, 2001, 22(9), 1483-1495.

[14] Palozza, P., Serini, S., Di Nicuolo, F., et al.: Prooxidant effects of $\beta$-carotene in cultured cells. Mol. Aspects Med., 2003, 24(6), 353-362.

[15] Young, A. J., Lowe, G. M.: Antioxidant and prooxidant properties of carotenoids. Arch. Biochem. Biophys., 2001, 385(1), 20-27.

[16] Witting, L. A.: Vitamin E and lipid antioxidants in free radical initiated reactions. In: Pryor, $W$. A. (ed.): Free radicals in biology. Academic Press, New York, 1980.

[17] Zingg, J. M., Azzi, A.: Non-antioxidant activities of vitamin E. Curr. Med. Chem., 2004, 11(9), 1113-1133.

[18] Valko, M., Leibfritz, D., Moncol, J., et al.: Free radicals and antioxidants in normal physiological functions and human disease. Int. J. Biochem. Cell Biol., 2007, 39(1), 44-84.

[19] Procházková, D., Boušova, I., Wilhelmová, N.: Antioxidant and prooxidant properties of flavonoids. Fitoterapia, 2011, 82(4), 513-523.

[20] Perron, N. R., Brumaghim, J. L.: A review of the antioxidant mechanisms of polyphenol compounds related to iron binding. Cell Biochem. Biophys., 2009, 53(2), 75-100.

[21] Egert, S., Rimbach, G.: Which sources of flavonoids: complex diets or dietary supplements? Adv. Nutr., 2011, 2(1), 8-14.

[22] Potter, J. D.: Cancer prevention: epidemiology and experiment. Cancer Lett., 1997, 114(1-2), 7-9.

(Hagymási Krisztina dr., Budapest, Szentkirályi u. 46., 1088 e-mail: hagymasi.krisztina@med.semmelweis-univ.hu) 